\title{
Implementation of the regulations of the board of directors of TVRI public agency on Non- Civil Servant in public television broadcasting agency in Indonesia
}

\author{
Erasmus Nagi Noi ${ }^{1}$, Alo Liliweri ${ }^{2}$, Lenny N. Tammunu ${ }^{3}$ \\ Nusa Cendana University ${ }^{1,2,3}$
}

nagi.damari.27@gmail.com

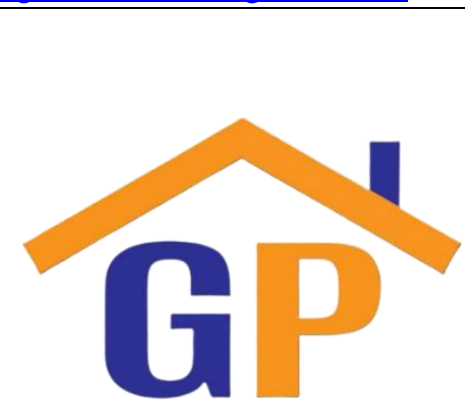

\begin{abstract}
Purpose: This research aims to analyze the implementation of the regulation of the board of directors of the TVRI public broadcasting institution regarding non-civil servants (Study at the Indonesian Television Public Broadcasting Institute (TVRI), East Nusa Tenggara Station.
\end{abstract}

Research methodology: In this study, the authors used an interpretive research paradigm. The interpretive approach aims to understand the "world of human experience". In this study, the total population was 110 people consisting of 27 non-civil servants and 83 civil servants. Furthermore, purposively, the researcher selected 11 people as informants with details of $1 \mathrm{Head}$ of the

\section{Article History}

Received on 2 September 2020 $1^{\text {st }}$ Revision on 6 October 2020 $2^{\text {nd }}$ Revision on 29 October 2020 $3^{\text {rd }}$ Revision on 30 November 2020 Accepted on 3 December 2020
Office as Key Informants and 10 non-civil servants as Ordinary Informants

Results: The conclusions of this study can be grouped into four aspects, namely actors, organizations, procedures, and techniques.

Limitations: this research only analyzes the implementation of policies on the development of Indonesian migrant workers' families in the field of economic empowerment in Kupang city.

Contribution: This research becomes scientific information for public administration science.

Keywords: Regulations, Implementation, Broadcasting agency, Non-Civil Servant

How to cite: Noi1, E. N., Liliweri, A., Tammunu, L. N. (2019). Implementation of the regulations of the board of directors of TVRI public agency on Non-Civil Servant in public television broadcasting agency in Indonesia. Annals of Management and Organization Research, 1(2), 95-106.

\section{Introduction}

Government agencies carrying out their activities functionally and administratively need support and an enormous contribution, especially concerning Human Resources. Human Resources that can contribute adequately to government agencies in carrying out their activities are directly proportional to the rights that must be issued to ensure employees' welfare. Priyono (2010) said that human or Human Resources (HR) are an essential element among various resources. In addition to Civil Servants, government agencies have the authority to appoint Government Employees with Employment Agreements. The understanding of Government Employees with the Working Agreement as stipulated in Article 1 number 4 of Law No. 5 of 2014 on The Civil Apparatus of the State, namely eligible Indonesian citizens, which is appointed based on the employment agreement for a particular time to carry out the duties of the government.

Based on both understandings described in Article 1 number 3 and 4 of Law No. 5 of 2014 on The State Civil Apparatus, Government Employees with Employment Agreements are not domiciled 
as public servants because they are appointed for a certain period to carry out their duties or work. Recruitment of Government Employees with Employment Agreements is one form of anticipation carried out by the government towards the high number of employee needs. However, it must still pay attention to the limited funds provided by the Budget of Opinion and State Expenditure or the Budget of Revenue and Local Expenditure because the payroll system of Government Employees with Work Agreements is taken from the Budget of Opinion and State Expenditure or the Budget of Revenue and Regional Expenditure.

The staffing status of Government Employees with the Employment Agreement based on Article 7 paragraph (2) of Law No. 5 of 2014 on The Civil Apparatus of the State, namely as an employee with an employment agreement appointed by the Officer of Staffing Has in common with the understanding of honorary personnel stipulated in Article 1 of Government Regulation of the Republic of Indonesia No. 48 of 2005 on the Appointment of Honorary Personnel to Be Civil Servants which explains that : An honorary officer is a person appointed by the Office of Staffing Or other officials in the government to perform certain duties at government agencies or whose income becomes the burden of the State Revenue and Expenditure Budget or the Regional Revenue and Expenditure Budget. The similarity between Government Employees and the Employment Agreement as explained in Article 7 paragraph (2) of Law No. 5 of 2014 on The Civil Apparatus of the State and Honorary Personnel as explained in Article 1.

As mentioned, Government Employees with Employment Agreements are appointed based on employment agreements for a certain period of time and carry out certain duties, in this case, in government. This is in accordance with the basis of the employment agreement for a particular time mentioned in Article 56 paragraph (2) of Law No. 13 of 2003 on Employment, which states that the employment agreement for a certain time is based on the period and completion of a particular work. Therefore, employment agreements for Government Employees with Employment Agreements are included in certain types of Time Work Agreements. The implementation of employment agreements for a particular time is used for permanent employees because there is a promised period for the person to work.

There is a difference in staffing status that needs to be considered by the relevant government agencies because both Civil Servants and Government Employees with their respective Employment Agreements have different rights and duties from each other. Therefore, there needs to be legal protection, especially for Government Employees with Employment Agreements, because in practice, there are still frequent violations related to the exercise of their rights as an employee is not fixed.

This is the author's background to write the status of non-civil servants equivalent to Government Employees with the Working Agreement at the Public Television Broadcasting Agency of the Republic of Indonesia (TVRI) East Nusa Tenggara Station. Based on Government Regulation No. 13 of 2005 on Public Television Broadcasting Agency of the Republic of Indonesia divides its employees into 2 (two) kinds, namely Civil Servants and Non-Civil Servants. Non-Civil Servants are then regulated in the Regulation of the Board of Directors of the Public Broadcasting Board of Television Of the Republic of Indonesia Number 02/PRTR/DIREKSI/TVRI/2017 on Non-Civil Servants in the Environment of the Public Television Broadcasting Agency of the Republic of Indonesia.

The development of TVRI Public Broadcasting Agency East Nusa Tenggara Station is inseparable from political life dynamics in the country. TVRI East Nusa Tenggara, for the first time, aired officially and regularly on August 24, 1962, precisely at the opening of the fourth Sea Games event in Jakarta under the Management of Bung Karno Foundation. In 1974 TVRI East Nusa Tenggara changed its status to the RRI Information Department's working system as the Directorate Of Television under the Directorate General of Radio TVRI East Nusa Tenggara and Film. Several times changed until finally through Law No. 32 of 2002 on broadcasting government regulation No.11 of 2005 on Public Broadcasting Agency TVRI East Nusa Tenggara Station was established as a public broadcasting institution established by the State.

TVRI Public Broadcasting Agency East Nusa Tenggara was established to serve public information that is neutral, independent non-commercial. Public broadcaster TVRI East Nusa Tenggara started in 1985 as TVRI East Nusa Tenggara Mobile Production Station (SPK) Kupang. TVRI SPK Kupang function was to cover news and produce packages of east Nusa Tenggara cultural arts events and then sent them to TVRI in Jakarta to be broadcast nationally. Along with the change in 
TVRI status of East Nusa Tenggara to Public Broadcasting Institution of East Nusa Tenggara Station since 2005, TVRI Public Broadcasting Agency east Nusa Tenggara station works in conjunction with other TVRI broadcasting stations, producing and broadcasting news and other programs.

TVRI Public Broadcasting Agency Office East Nusa Tenggara Station has a duty as a public broadcasting media agency branch of East Nusa Tenggara province located on the road W.J. Lalamentik Oepoi Kupang. TVRI East Nusa Tenggara Station has a broadcasting station based in Kupang, East Nusa Tenggara and supported by 21 transmitters spread across 18 districts and cities. Every day TVRI East Nusa Tenggara broadcasts for 4-5 hours a day: 16.00-21.00 WITA plus news broadcasts through Virtual Private Network (VPN) at 10.00-12.00 at 20.00 emitted directly from W.J. Lalamentik Street Kupang, East Nusa Tenggara.

TVRI is supported by 135 employees spread across TVRI East Nusa Tenggara Station office located in Kupang and has 21 transmitters in daily operation. On every TVRI transmitter station in 18 districts and cities throughout East Nusa Tenggara. The 18 districts include Belu Regency, Malacca Regency, North Central Timor Regency, South Central Timor Regency, Rote Ndao Regency, Kupang City, Sabu Raijua Regency, Alor Regency, Lembata Regency, East Flores Regency, Sikka Regency, Ende Regency, West Sumba Regency, East Sumba Regency, Bajawa Regency (has 3 transmitters located in Boawae, Bajawa, Aimere), Nagekeo, Labuan Bajo and Ruteng.

There are 92 workers at TVRI Public Broadcasting Station in East Nusa Tenggara, with the following details.

Characteristics of East Nusa Tenggara Station TVRI Employees Based on Staffing Status

\begin{tabular}{|c|c|c|c|}
\hline No & Staffing Status & Amount & Percentage \\
\hline 1 & Civil Servants & 65 & $71 \%$ \\
\hline 2 & Non-Civil Servants & 27 & $29 \%$ \\
\hline 3 & Honorer & - & - \\
\hline \multicolumn{2}{|c|}{ Amount } & 92 & $100 \%$ \\
\hline
\end{tabular}

Source: LPP TVRI East Nusa Tenggara Station 2017

In the implementation of employee recruitment, the Public Television Broadcasting Agency of the Republic of Indonesia (TVRI) recruits Non-Civil Servants based on employment agreements agreed by both parties. The position of Non-Civil Servant in this case as a contract officer is based on employment agreements and is not the same as that of civil servants working at the Public Television Broadcasting Agency of the Republic of Indonesia. The employment agreement used for contract employees is the Specific Time Employment Agreement. In contrast to Government Employees with Employment Agreements, Non-Civil Servants of TVRI Public Broadcasting Agency also receive old age benefits and structural positions.

The problem is, the work agreement made between the Public Broadcasting Agency of the Republic of Indonesia and non-civil servants does not apply to all provisions as stipulated in the Regulation of the Board of Directors of the Indonesian Public Broadcasting Agency. Law No. 13 of 2005 concerning Non Civil Servants in the Public Television Broadcasting Agency of the Republic of Indonesia. Problems that arise in implementing this Board of Directors Regulation include the absence of structural positions and old age benefits for non-civil servants. These two things are the differentiator and superiority of non-civil servants Public Broadcasting Institutions TVRI with Civil Servants who have a Work Agreement. This is the reason for the researcher to conduct this research to analyze how the basic rights that should be received by non-civil servants, as well as the protection contained in the work relationship between the TVRI Public Broadcasting Institute as an employer and non-civil servants, are implemented as regulated in Regulation of the Board of Directors of the Republic of Indonesia Public Broadcasting Agency Number 02 / PRTR / DIREKSI / TVRI / 2017 concerning Non-Civil Servants in the Public Broadcasting Agency of the Republic of Indonesia Television. 


\section{Literature review}

\subsection{Public policy}

Wahab (2008) argues that the term policy itself is still cross-opinion and is a debate of experts. Thus to understand the policy terms, Wahab (2008:40-50) provides the following guidelines: 1). Policies must be distinguished from decisions, 2). Actual policies are not necessarily indistinguishable from the administration, 3). Policies include behavior and expectations, 4). Policies include the absence of action or action, 5). Policies usually have final results to be achieved, 6). Each policy has a specific purpose or objective whether explicit or implicit, 5). Policies usually have final results to be achieved, 6). Each policy has a specific purpose or objective, either explicit or implicit,7). The policy arises from a process that lasts all the time, 8). Policies include interorganizational and intra-organizational relationships, 9). Public policy though is not exclusive regarding the key role of government agencies and 10). The policy is formulated or defined subjectively. According to Winarno (2007: 15), the term policy (policy term) may be used widely as in "Indonesian foreign policy", "Japan economic policy", and or may also be used to be something more specific, such as for example if we say government policy on de-bureaucracy and deregulation.

Islamy (2009:17) policy should be distinguished by wisdom. Policy is translated by different policies meaning wisdom, which means wisdom. The understanding of wisdom requires further consideration, while the policy includes the rules contained there. Friedrich 1969 in Agustino (2016: 16) states that policy is a series of actions proposed by a person, group, government or a certain environment by showing the constraints of opportunities for implementing the proposed policy in order to achieve certain goals. Another policy definition put forward by Nugroho (2006: 23) makes a formulation of understanding about public policy. First, public policies are policies made by state administrators or public administrators. So, public policy is everything that the government does and doesn't do. Second. The public policy regulates life together or public life, not the life of an individual or an individual. Public policy governs everything in the domain of a public administrator institution. The public policy regulates common problems or personal or group problems that have become problems of the entire community in that area. Third, it is said to be a public policy if the benefits obtained by people who are not direct users of the products produced are far greater than direct users. Rose as quoted by Winarno (2007:17) also suggested that the policy should be understood as a series of slightly related activities along with consequences for those concerned rather than as stand-alone decisions. The two experts' opinions can at least explain that interchanging policy terms with decisions is wrong. The policy is understood as the direction or pattern of activity and not just a decision to do something.

The meaning of policy as a series of activities or actions added by Friedrich 1969 in Agustino (2016: 16) defines policy as an action that leads to goals proposed by a person, group, or government in a certain environment in connection with certain obstacles while looking for opportunities to achieve goals or realize the desired goals to achieve a goal. According to Dunn (2003: 25), formulating public policy is based on various main stages. The stages in this public policy are described as shown below:
1. Problem Formation
2. Policy Formulation
3. Policy Adaption
4. Policy Implementation
5. Policy Evaluation

\subsection{Policy implementation}

According to Lester and Stewart, policy implementation is viewed in a vast sense, is a tool of legal administration in which various actors, organizations, procedures and techniques are together to carry out policies in order to achieve the desired impact or purpose (Winarno.2002:28). Implementation on the other hand is a complex phenomenon that may be understood as a process, output or as a result. According to Patton and Sawicki (in Nogi, 2003:9) the implementation relates to various activities directed at realizing the program, in which in this position the executive sets out how to organize, interpret and implement the selected policies. 
Mazmanian and Sabatier define policy implementation as (Agustino, 2008:139): "The implementation of basic policy decisions, usually in the form of laws, but also in the form of important executive orders or decisions or decisions of the governing body. Typically, the decision identifies the problem you want to address, mentions the task or goal you want to achieve, and the various ways to structure or manage the implementation process". Van Metter and Van Horn (1975:475) said that the policy's implementation as: "Actions taken by either individuals or governmental or private officials or groups are directed at achieving the objectives outlined in the policy decisions". The same is also stated by Grindle (1980) in Agustino (2006:139): "The measurement of implementation success can be seen from the process is determined by questioning whether the implementation of the program in accordance with the specified is looking at the program action of the individual project and secondly whether the objective of the program is achieved, Policy implementation is the decision-making stage between the formation of a policy."

According to Dunn (2003:132) is the implementation of policy measures within a certain period. Many variables influence the successful performance of policies, both individual and group or institution. The implementation of a program involves policymakers' efforts to influence the behavior of implementing bureaucrats to be willing to provide services and regulate the behavior of target groups. The success of policy implementation is determined by an implementation model that is able to ensure the complexity of the problem to be solved through a particular policy. This policy implementation model is certainly expected to be an increasingly operational model so as to explain the causality relationship between variables related to the policy. There are several types of policy implementation including the following:

1. Grindle Implementation Model (1980)

Grindle (in Subarsono, 2005:93) Says the success of implementation is influenced by two variables: the content of the policy and implementation complexity. 1). The variables of the content of this policy include: First, the extent to which the interests of the target group or the target groups are included in the policy content; Second, The types of benefits received by target groups; Third, The extent of the desired change of a policy. A program aimed at changing the attitudes and behaviors of the target group is relatively more challenging to implement than a program that simply provides credit assistance or rice assistance to the poor: Kempat, whether the location of a program is appropriate; Fifth, whether a policy has mentioned its implementors in detail and the Sixth, whether adequate resources support a program. Whereas, 2). Policy environment variables include: First, how much power, interests, and strategies the actors involved in policy implementation have; Second, the characteristics of institutions and regimes in power; level of compliance and responsiveness of the target group.

2. Van Meter and Horn Implementation Model (1975)

According to Meter and Horn, five variables affect implementation performance, namely, policy standards and objectives, resources, communication between organizations and strengthening activities, characteristics of implementing agencies, and conditions, social, economic, and political.

3. Mazmaiman and Sabatier Implementation Model (1983)

According to Mazmanian and Sabatier (1983) there are three groups of variables that affect the success of implementation, namely: (1) the characteristics of tractability of the problems; (2) characteristics of policy/statute to structure implementation; (3) non statutory variables affecting implementation.

\subsection{Concept of government employees with employment agreements or in other words Non-Civil Servants}

Government agencies have the authority to appoint In addition to Civil Servants and Government Employees with employment agreements. The understanding of Government Employees with the Working Agreement as stipulated in Article 1 number 4 of Law No. 5 of 2014 on The Civil Apparatus of the State, namely eligible Indonesian citizens, which is appointed based on the employment agreement for a certain time in order to carry out the duties of the government. Based on the two understandings described in Article 1 number 3 and 4 of Law No. 5 of 2014 on the State Civil 
Apparatus it can be known that PPPK (Government Employees with Employment Agreements) are not domiciled as public servants because the employee is appointed for a certain period of time in order to carry out his duties or work.

Recruitment of Government Employees with Employment Agreements is one form of anticipation carried out by the government against the high number of employee needs but should still pay attention to the limited funds provided by the State Revenue and Expenditure Budget/Local Revenue and Expenditure Budget because the payroll system of Government Employees with Work Agreements is taken from the State Revenue and Expenditure Budget/Local Revenue and Expenditure Budget. The staffing status of Government Employees with the Employment Agreement based on Article 7 paragraph (2) of Law No. 5 of 2014 on The Civil Apparatus of the State, namely as an employee with an employment agreement appointed by the Officer of Staffing Has in common with the understanding of honorary personnel stipulated in Article 1 of Government Regulation of the Republic of Indonesia No. 48 of 2005 on the Appointment of Honorary Personnel to Be Civil Servants which explains that: An honorary officer is a person appointed by the Office of The Trustee of Staffing or other officials in the government to perform certain duties at government agencies or whose income becomes the burden of the State Revenue and Expenditure Budget or the Regional Revenue and Expenditure Budget.

\section{Research methodology}

In this study, the authors used an interpretive research paradigm. This research paradigm is used as the right paradigm in qualitative research. The interpretive research paradigm itself is a paradigm that emphasizes not the positivity of a reality or research object, but rather on the relationship between various elements related to the object of research. Cohen and Manion as cited by Liliweri (2018: 48), says that the interpretive approach aims to understand the "world of human experience." This causes interpretive researchers end to rely on researchers' views on inter-human interactions related to the situation being studied (Liliweri, 2018). In this study the total population was 110 people consisting of 27 non-civil servants and 83 civil servants. Furthermore, purposively, the researcher selected 11 people as informants with details of 1 Head of the Office as Key Informants and 10 non-civil servants as Ordinary Informants.

\section{Results and discussions}

Government agencies in carrying out their activities both functionally and administratively need support and a large contribution, especially concerning Human Resources. The existence of Human Resources that are able to contribute adequately to government agencies in carrying out their activities is directly proportional to the funds that must be spent to finance employees.

The existence of a source of funds for employee financing is important and vital because a good and correct wage system can affect employee performance. Such conditions require government agencies to regulate staffing management so that there is no gap between the need for Human Resources and the costs incurred to finance staffing.

Law No. 5 of 2014 on State Civil Apparatus divides state civil servants into 2 (two) kinds, namely civil servants and government employees with working agreements. The understanding of civil servants in accordance with Article 1 number 3 of Law No. 5 of 2014 on Civil Servants of the State, namely certain eligible Indonesian citizens, is appointed as a permanent civil servants officer by the Office of the Minister of Staffing to occupy government positions. In addition to civil servants, government agencies have the authority to appoint Government Employees with Working Agreements. The understanding of Government Employees with Working Agreements as stipulated in Article 1 number 4 of Law No. 5 of 2014 on Civil Apparatus of The State, namely indonesian citizens who meet certain conditions, who are appointed based on the employment agreement for a certain time in order to carry out the duties of the government.

Based on the two understandings described in Article 1 number 3 and 4 of Law No. 5 of 2014 on the State Civil Apparatus it can be known that Government Employees with Employment Agreements are not domiciled as public servants because the employee is appointed for a certain period to carry out his duties or work. Recruitment of Government Employees with Employment Agreement is one form of anticipation carried out by the government towards the high number of 
employee needs. However, it must still pay attention to the State Budget / Budget's limited funds because the payroll system of Government Employees with Working Agreement) is taken from the State Revenue and Expenditure Budget / Regional Revenue and Expenditure Budget.

The staffing status of Government Employees with Employment Agreement based on Article 7 paragraph (2) of Law No. 5 of 2014 on Civil Servants of the State, namely as employees with employment agreements appointed by the Office of the Trustee of Staff has similarities to the understanding of the honorary workforce stipulated in Article 1 of Government Regulation of the Republic of Indonesia No. 48 of 2005 on the Appointment of Honorary Personnel to Be Civil Servants which explains that: An honorary officer is a person appointed by the Office of Staffing Or other officials in the government to perform certain duties at government agencies or whose income becomes the burden of the State Revenue and Expenditure Budget or the Regional Revenue and Expenditure Budget. The similarities between Government Employees and Employment Agreements as explained in Article 7 paragraph (2) of Law No. 5 of 2014 on the Appointment of Honorary Personnel into Civil Servants are both appointed by the Office of The Director of Staffing, for a certain period of time, and carry out certain duties at government agencies. This Non-civil servants rating is in accordance with Government regulations No. 13 of 2005 on Public Broadcasting Institutions TVRI and internal regulations of TVRI in Board of Directors Regulation No. 2/2017.

In Government regulations No. 13 of 2005 on TVRI Public Broadcasting Agency article 41 paragraph 1 states that TVRI employees are central civil servants appointed under the provisions of applicable laws and regulations, and not civil servants appointed by the board of directors under employment agreements. From interviews with researchers, researchers classified the results of the discussion in 4 topics, namely, actors, organizations, procedures, and techniques.

This concept is taken from the concept of James P. Lester and Joseph Stewart in their book Public Policy: An Evolutionary Approach (1996). Lester and Stewart (1996:97-98) revealed that implementation was a stage of the policy process immediately after the law was passed. Implementation is considered most broadly, meaning the administration of laws in which various actors, organizations, procedures, and techniques work together to implement policies adopted in an effort to achieve policy or program objectives. Previous implementation definitions ranged from broad conceptualization to a more limited or dichotomy view that implementation was achieved or not achieved.

In addition to these two definitions, Lester and Stewart revealed that implementation can be conceptualized as a process or a series of decisions and actions directed at implementing previous opportunistic federal legislative decisions. For example, in the United States, Lester and Stewart describe five repetitive activities or functions usually occurring in the policy implementation process. First, the state legislature passed a law allowing states to begin hearings related to the legislation. second, state agencies perform administrative rulemaking and establish administrative routines to implement laws, the availability of appropriate resources, including the money and human capital that the state needs to implement the policies as intended. Fourth, legislators monitor and, through the application of sanctions and awards, enforce local compliance with laws and regulations. Fifth, after some experience with its operations, lawmakers redesigned the policy in response to design flaws or loss of opportunities. Therefore, the essential characteristics of the implementation process are the timely and satisfactory performance of certain tasks necessary to carry out the intent of the legislation. This is most often referred to as compliance.

Implementation can also be defined in terms of output, or the extent to which the program's objectives are supported, such as the level of spending made for a program or the number of violations issued for failing to comply with implementation directives. Finally, at the highest level of abstraction, the implementation results imply that there have been some measurable changes in the larger issues addressed by programs, public law, or judicial decisions. In short, implementation as a concept involves all these activities. Although it is a complex phenomenon, it can be understood as a process, output, and result. It also involves a number of actors, organizations, and control techniques.

The actors referred to in this study are the appointed Non-civil servants and the board of directors of Public Broadcasting Institutions TVRI which in this case is represented by the Head of TVRI Public Broadcasting Agency East Nusa Tenggara Station. The organization is TVRI Public Broadcasting Agency East Nusa Tenggara Station, while the procedures and techniques are the procedure of appointment of non-civil servants and the technique of the implementation of the main 
duties and functions of the Non-civil servants in the scope of TVRI Public Broadcasting Agency East Nusa Tenggara Station. These four topics are indicators of the successful implementation of non-civil servants appointment policy in the scope of TVRI Public Broadcasting Agency East Nusa Tenggara Station. Because in each of these topics there are several aspects such as, discipline, implementation of basic duties and functions, salaries and allowances, education and training, and so on that also affect the performance of Non-civil servants. In short, the successful implementation of pbpns appointment policy is measured not only by how Non-civil servants performs its duties and responsibilities, but also from how TVRI Public Broadcasting Agency East Nusa Tenggara Station as an organization is able to provide opportunities and open opportunities for improved PBPNS performance.

Similar things are discussed in research conducted by Harmin entitled "Implementation of The Discipline Policy of the State Civil Apparatus in the Regional Staffing Agency of Parigi Moutong Regency", e-journals (2018: 97-104) and Emilia H (2018) on "Implementation of PP 53 Year 2010 on Civil Servant Discipline at the Riau Islands Regional Financial and Asset Management Agency", in the Journal of Raja Ali Haji Maritime University (UMRAH). In the study, Harmin and Emilia emphasized ASN's role as the main resource of the implementation of basic tasks and functions need to be professional in order for the wheels of government to run properly and avoid corruption, collusion, and nepotism. As in Harmin and Emilia's research, the study also emphasizes that one measure of work professionalism is employee discipline. Employee discipline affects the work and is also influenced by several other aspects such as salary giving, Human Resources quality, equalization of basic duties and functions, facilities, technology, infrastructure, social and economic factors, and employee education background.

The same issue was also discussed in research conducted by Karim (2015: 84-95) entitled "Implementation of Civil Servant Discipline Implementation of Central Sulawesi Provincial Staffing Agency". In the results of research on the implementation of employee discipline enforcement policy in the scope of Central Sulawesi Provincial Government found that 1) Communication in this case socialization about clarity and consistency has not gone well, this is shown by the communication barriers in the form of socialization carried out the implementers have not been optimally implemented. 2) Resources are not running well, due to the limitations of Human Resources, placement is not in the field of science and supporting facilities/ infrastructure is inadequate. 3) Disposition, lack of precise completion of existing work due to the large volume of work, but not accompanied by the number of employees and the quality of employees and the placement of employees based on expertise. 4) The mechanism of work of employees in carrying out their Tupoksi, admittedly goes quite well, however there are still many violations including discipline of working time and lack of thoroughness in the work, but that is not to be questioned.

These things will also later be discussed in this study. From the results of the interview, researchers found that the effectiveness and efficiency of the implementation of non-civil servants appointment policy in TVRI Public Broadcasting Agency is determined by how the non-civil servants understands its basic tasks and functions, understands the distribution of its duties; TVRI Public Broadcasting Agency is able to organize good mechanisms and working organizations, as well as Human Resources that are constantly updated based on the needs and demands of work in TVRI Public Broadcasting Agency East Nusa Tenggara Station.

At the end of the discussion, researchers will discuss the inhibitory factors and solutions that can be provided in overcoming the obstacles in implementing Non-Civil Servants' appointment policy in the scope of TVRI Public Broadcasting Agency East Nusa Tenggara Station. This discussion is very useful for TVRI Public Broadcasting Agency to improve the quality of Human Resources and prepare the next non-civil servants recruitment process as discussed by Herni (2017) about "Implementation of State Civil Apparatus Discipline within the Scope of Regional Device Task Force" (Study at The Public Works Office of North Lampung Regency), in the Journal of Scientific Law of the State Administration of the Faculty of Law, University of Lampung. In his research, Gita stated that: 1). Implementation of Civil Servant Discipline Regulation based on Government Regulation No. 53 of 2010 on the discipline of Civil Servants in The Public Works Service of North Lampung Regency has been implemented since the regulation was enacted. But in reality the regulation has not been optimally implemented because there are still many Civil Servant Employees in the Public Works Office of North Lampung Regency who are still conducting disciplinary budgets. 
And 2) The obstacles that exist in the implementation of civil servant discipline in the scope of the Regional Device Task Force in the Public Works Office of North Lampung Regency include the lack of facilities and infrastructure, still low awareness of employees for discipline in carrying out their duties such as delay in entering work, not entering the office, still lack of supervision system carried out by superiors. Regional Device Task Force leadership in the Public Works Office environment of North Lampung Regency has a major role in implementing Government Regulation No. 53 of 2010 on Civil Servant Discipline, especially in improving employee discipline against working hours. Not the maximum leadership of the Head of Section and Subsection in the Public Works Office of North Lampung Regency in the discipline supervision of Civil Servants, providing coaching and being an example for Civil Servants causes civil servant discipline to discipline provisions still not running smoothly.

\subsection{Actor}

Lester and Stewart (1996:98-101) explained that the actors who participated in the implementation of the policy were bureaucracy, legislatures, courts, suppressor groups, and community organizations. Both cited these five groups as actors because of their background in social conditions in the United States, these five groups play an important role in the implementation or implementation of policies.

According to the authors, these five actors can be applied in this research on the policy of appointing Non-Civil Servants. The actors in question are various parties involved in the implementation of the policy of appointment of Non-Civil Servants, namely the Board of Directors of TVRI Public Broadcasting Agency East Nusa Tenggara, Non-Civil Servants appointed by the Board of Directors of TVRI Public Broadcasting Agency East Nusa Tenggara Station, head of TVRI Public Broadcasting Agency representing bureaucracy, legislative bodies and juridical institutions, while non-civil servants appointed represent suppressive groups and community organizations that are controllers for the implementation of the policy.

The aspects used to measure this are:

1. Understanding the appointment of Non-Civil Servants

The respondents in this study clearly understood the policy of appointing Non-Civil Servants at TVRI Public Broadcasting Agency. The respondents stated that the association of Non-Civil Servants is following PP No. 13 of 2005 on TVRI Public Broadcasting Agency and TVRI internal regulations in Board of Directors Regulation No. 2 of 2017. The appointment of NonCivil Servants has also gone through appropriate processes including socialization and signing of ties between TVRI directors and non-civil servants.

2. Task execution/SOP

There is a difference of view about the implementation of sop-appropriate tasks, some of which state that SOP has been well executed but according to some respondents it has been assessed as yet, due to the limited manpower/personnel and low work awareness of some employees. There are still sections that do not have a description of the duties for each profession/position, but due to the limitations of employee personnel must be concurrent duties.

3. Educational background

In its implementation, TVRI Public Broadcasting Agency East Nusa Tenggara prioritizes skills over educational background. The interview results found that all respondents agreed that many NonCivil Servants at TVRI Public Broadcasting Agency East Nusa Tenggara were not placed according to their educational background. Most employees are placed according to the needs of the agency and the skills of its employees.

4. Mastery of technology

Non-Civil Servants are filled by most young people who are millennials and have a high learning spirit, and there are also professional training that the institution holds. This profession requires them to always be updated and literate in the field of technology that exists as well as the latest. Respondents who have a background in communication technology education admit to having mastered existing technologies because it corresponds to their educational background. While some respondents who are not from this education admit that they have to learn and try themselves (self-taught) to master the skills and skills in this field in order to answer the demands of their work. 
5. Division of tasks

When it come to equalization in terms of division of duties, some respondents say that there has not been a fairness that should be seen. This is evident from the stacking of jobs in certain parts, while others are seen to lack much work.

6. Discipline

In relation to discipline, 10 respondents related to employee discipline, 3 people who said that non-civil servants have been disciplined, 2 people said that discipline is still measured in quantity of finger print records, while the quality has not been measured While 6 others said that the employees of TVRI Public Broadcasting Agency East Nusa Tenggara still many are not disciplined. Three of them said that many employees who only do finger come and go but do not carry out their duties or are not present at the office during effective working hours.

7. Salary awarding

Regarding the awarding of employee salaries, all respondents stated that the system of providing salaries after their appointment to become Non-Civil Servants is sufficient and satisfactory. This is shown from the system of equal pay distribution of Civil Servants and based on the level of education and length of work at TVRI Public Broadcasting Agency East Nusa Tenggara until their appointment in 2017.

8. Equalization of Professional Training between Civil Servants and Non-Civil Servants.

Based on the results of interviews with respondents, the researchers obtained different answers between the two groups. 5 (five) respondents said that the training has been given evenly for both Civil Servants and Non-Civil Servants according to their respective professions' needs.

\subsection{Organization}

Organizations play an essential role in implementing a policy. Citing Van Meter and Van Horn's implementation of the Top-down approach, Lester and Stewart (1996:57) described the implementation of public policy as "actions taken by individuals/officials or governmental or private groups directed at achieving the goals outlined in policy decisions. Van Meter and Van Horn (1975) say that many independent variables separate the road connecting public policy and work achievement.

In this section, the author will describe the behavior of the organization of TVRI Public Broadcasting Agency East Nusa Tenggara in the implementation of the policy of appointing NonCivil Servants in the scope of TVRI Public Broadcasting Agency East Nusa Tenggara judging by some of the things below:

1. Department of Non-Civil Servants

The policy of appointing Non-Civil Servants by TVRI Public Broadcasting Agency East Nusa Tenggara is indeed able to answer limited Human Resources needs. However, respondents argue that it is still necessary to add Non-Civil Servants to cover Human Resources shortages in units or parts of TVRI Public Broadcasting Agency East Nusa Tenggara. Eight respondents revealed this in his interview. The respondents argued that the placement of Non-Civil Servants in each section was not following the needs of employees at TVRI Public Broadcasting Agency East Nusa Tenggara.

2. Implementation of Basic Duties and Functions of Non-Civil Servants

In practice in the field the low availability of Human Resources requires these employees to carry out tasks that are not in the primary duties and functions. This leads to overlap in the implementation of duties and responsibilities.

\subsection{Procedure}

From the answer of the respondents it is known that in general the recruitment process has fulfilled the stages of implementation that have been established but in terms of the educational background of the Non-Civil Servants many do not meet the standards. The selection process that is still centered in the central TVRI is considered a form of non-transparent process of appointment of Non-Civil Servants. This is demonstrated by the response from respondents who assessed the lack of transparency in this appointment process. 


\subsection{Techniques}

The technique referred to in this study is how non-civil servants perform their basic and dungsi duties. Although the basic duties and duties and description stipulated by the boss are fair and equitable, the process of execution and completion of such tasks is carried out differently by each person. The same is true at TVRI Public Broadcasting Agency East Nusa Tenggara. For daily duties in office active hours (08.00 - 16.00) each employee, both Civil Servant and Non-Civil Servant performs duties at their respective work posts. After that hour, which is from $16.00-21.00$, the employees are involved in the show's production process or show. For this activity some employees from other units, in addition to news units and the like, are asked to take part (of course with the appropriate honor pay). This kind of working practice is a form of teamwork. Some respondents expressed this in their interviews. They admit that they often carry out tasks and other unit work. However, agency leaders are already thinking about that. Teamwork systems can overcome existing Human Resources limitations by providing additional honors or payments.

\section{Conclusion}

Based on previous research and discussion results, it can be concluded that there are four important aspects of the implementation of personnel policies in TVRI, namely actors, organizations, procedures, and techniques. 1). Actors; Non-Civil Servants appointed have understood the policy of appointing Non-Civil Servants. Non-Civil Servants understand their responsibilities both in terms of implementing primary duties and functions, division of responsibilities, discipline, and mastery of technology. This becomes the aspects assessed not only for the benefit of their appointment but also for ensuring the implementation of their responsibilities and performance improvement after being appointed as Non-Civil Servants. 2). Organization; TVRI Public Broadcasting Agency East Nusa Tenggara as the implementing organization of the policy of appointing Non-Civil Servants has built an organizational structure that can ensure equalization of its employees' welfare and duties. But despite getting the same basic duties and duties as civil servants, non-civil servants do not get the opportunity to develop their careers structurally. This is because the TVRI Public Broadcasting Agency East Nusa Tenggara does not give structural positions to their Non-Civil Servants. 3). Procedure; The high number of employees with the background of the last education of High School, Junior High School, and Darah School is minimized by TVRI Public Broadcasting Agency East Nusa Tenggara in order to improve the quality of performance and production of work. The provision of training can be a way out to train and educate employees who do not have an educational background that suits the profession, but it will be more effective and efficient if given to employees who already have an educational background equivalent to the profession required in Lemabaga Public Broadcasting TVRI East Nusa Tenggara. Another issue also found is related to the procedure for appointment of Non-Civil Servants is the tendency to raise close relatives and relatives and the lack of transparency of the selection process of Non-Civil Servants. This needs to be avoided in order to improve the pattern of healthier and professional working relationships among employees at TVRI Public Broadcasting Agency East Nusa Tenggara. 4). Techniques; The implementation of basic duties and functions (basic duties and duties) of Non-Civil Servants still has inequalities and discrepancies. Respondents admitted that even if they had performed their duties according to the details of the task, the limited resources and facilities kept much of their work delayed or not completed on time.

\section{Limitation and study forward}

This study only discussed staffing policy for non-civil servants in public broadcaster TVRI East Nusa Tenggara station. The results do not describe the phenomenon in general. Results and discussions may differ from similar policies in other institutions. Therefore, broader research can be a great addition to complement the shortcomings of this study. Varied research methods are recommended by other researchers who want to examine similar cases so that the results found can be comparisons that enrich information more information that looks at staffing policies for non-public servants.

\section{References}

Agustino, Leo. (2008). Dasar-dasar kebijakan publik. Bandung: Alfabeta.

Dunn, William N. (2003). Analisis kebijakan publik. Yogyakarta: Gadjah Mada University Press. 
Emilia, Helmi. (2018). Implementasi Peraturan Pemerintah Nomor 53 Tahun 2010 tentang Displin Pegawai Negeri Sipil pada Badan Pengelolaan Keuangan dan Aset Daerah Provinsi Kepulauan Riau. E-Jurnal Universitas Maritim Raja Ali Haji.

Grindle, M.S. (1980). Public choices and policy change: the political economy of reform in developing countries. London: The Johns Hopkins University Press.

Harmin. (2018). Implementasi kebijakan disiplin Aparatur Sipil Negara di Badan Kepegawaian Daerah Kabupaten Parigi Moutong. E-jurnal Katalogis, 6(1), 97-104.

Herni, S. G. (2017). Implementasi displin Aparatur Negara dalam lingkup Satuan Kerja Perangkat Daerah (Studi di Dinas Pekerjaan Umum Kabupaten Lampung Utara). Jurnal Ilmiah Hukum Admisnistrasi Negara Fakultas Hukum Universitas Lampung, 4(2).

Islamy, M Irfan. (2009). Prinsip-prinsip perumusan kebijaksanaan negara. Jakarta: Bumi Aksara.

Karim, Firdaus MG. Abd. (2015). Implementasi penegakan disiplin Pegawai Negeri Sipil Badan Kepegawaian Daerah Provinsi Sulawesi Tengah. e-jurnal Katalogis, 3(2), 84-95.

Lembaga Penyiaran Publik Televisi Republik Indonesia. (2017). Peraturan Direksi Lembaga Penyiaran Publik Televisi Republik Indonesia No. 02/PRTR/DIREKSI/TVRI/2017 tentang Pegawai Bukan Pegawai Negeri Sipil di Lingkungan Lembaga Penyiaran Publik Televisi Republik Indonesia. Direksi LPP TVRI.Jakarta.

Lester, James P \& John Stewart, Jr. (1996). Public policy: an evolutionary approach. USA: West Publising Company.

Liliweri, Alo. (2018). Paradigma penelitian Ilmu Sosial. Yogyakarta: Pustaka Pelajar.

Mazmanian, D. A. and P. A. Sabatier (1983). Implementation and public policy (p. 25). Glenview, IL: Scott, Foresman.

Nogi Hesel S.Tangkilisan, (2003). Implementasi kebijakan publik: transformasi pemikiran, Yogyakarta: Y.A.P.

Nugroho, Riant. (2012). Public policy. Jakarta: Elex Media Komputindo.

Pemerintah Indonesia. (2014). Undang-undang No.5 tahun 2014 tentang Aparatur Sipil Negara. Lembaran Negara RI tahun 2014. No.6. Sekretariat Negara. Jakarta.

Pemerintah Indonesia. (2010). Peraturan Pemerintah No. 53 Tahun 2010 tentang Disiplin Pegawai Negeri Sipil. Lembaran Negara. No. 74. Sekertariat Negara. Jakarta

Pemerintah Indonesia. (2005). Peraturan Pemerintah No. 13 Tahun 2005 tentang Lembaga Penyiaran Publik Televisi Republik Indonesia. Lembaran Negara RI. No. 30. Sekeretariat Negara. Jakarta.

Pemerintah Indonesia. (2005). Peraturan Pemerintah No. 11 Tahun 2005 tentang Penyelenggaraan Penyiaran Lembaga Penyiaran Publik. Lembaran Negara. No. 28. Sekeretariat Negara. Jakarta.

Pemerintah Indonesia. 2005. Peraturan Pemerintah No.48 Tahun 2005 tentang Pengangkatan Tenaga Honorer Menjadi Calon Pegawai Negeri Sipil. Lembaran Negara RI tahun 2005. No.122. Sekretariat Negara. Jakarta.

Pemerintah Indonesia. (2003). Undang-undang No.13 Tahun 2003 tentang Ketenagajerjaan. Lembaran Negara RI. No. 39. Sekretariat Negara. Jakarta.

Pemerintah Indonesia. (2002). Undang-undang No.32 Tahun 2002 tentang Penyiaran. Lembaran Negara. No. 139. Sekretariat Negara. Jakarta.

Priyono. (2010). Manajemen Sumber Daya Manusia. Taman Sidoarjo: Penerbit Zifatama Publisher.

Subarsono, A. G. (2005). Analisis kebijakan public konsep, teori, dan aplikasi. Yogyakarta: Pustaka Belajar.

Van Meter, Donal dan Van Horn, Carl E. (1975). The policy implementation process conceptual frame work. Journal Administration and Society.

Wahab, Solichin Abdul. (2008). Analisis kebijaksanaan: Dari formulasi ke implementasi kebijaksanaan negara. Jakarta: Bumi Aksara.

Winarno, Budi. (2008). Kebijakan publik teori dan proses. Yogyakarta: MedPress. 